\title{
INCREASING CHILDREN'S CONSCIOUSNESS IN MOTORCYCLING OF MOTORCYCLE ON RAILWAY (study in Demak Regency)
}

\author{
Ida Musofiana, Rizki Adi Pinadito \\ Lecturer Faculty of Law Sultan Agung Islamic Unversity Semarang \\ Ida.musofiana@unissula.ac.id \\ Rizkyadi@unissula.ac.id
}

\begin{abstract}
Abstrack
Traffic accidents are a global health problem. The number of traffic accidents each year has increased and traffic accidents in Indonesia are assessed by the World Health Organization $(\mathrm{WHO})$ as the third killer after heart disease and tuberculoces. This study aims to examine how exactly the level of knowledge of parents in Demak District to their children who ride motorcycles on the highway. The method used in this research is descriptive qualitative, with research location in Demak Regency. In order to obtain data in the field, data collection techniques such as observation and structured interviews, and using data analysis. The role of parents as a mentor is accompanying children while driving, and monitor the child if you want to ride a motorcycle, check the safety of driving. The purpose of this research is to become the agenda of socialization of safety riding for the general public in order to increase awareness of the importance of maintaining traffic safety on the highway, and reminding each other if there is violation of traffic rules. One of them reprimanded underage riders so as not to speed-kebutan or more careful.
\end{abstract}

Keywords : legal awareness, child, traffic.

\section{A. INTRODUCTION}

Indonesia is a legal country that gives consequences of all the daily activities of its citizens governed by law. One of the rule of law in Indonesia Law Number 22 Year 2009 about Traffic and Road Transportation. That is traffic regulations, containing orders and restrictions that must be obeyed by all communities in order to maintain safety and security in traffic.

Safety and security while driving on the road must be maintained by realizing discipline. Discipline is formed on respecting, respecting, and obeying both written and unwritten rules. All these things are run without complaint and accept sanctions if it has violated the existing rules. Traffic discipline means one's actions to obey what is allowed and what not to do when driving / on the road. Such terraces are obedient to traffic signs, traffic signals, and speed limits in driving.

In Indonesia, motorcycles enter the vehicle most in demand by the public. Motorists and drivers are people who drive motorcycles.
The increasing number of traffic accidents from year to year resulted in the emergence of the term highway as a killer in Indonesia. Although the rules for restricting the use of taxes have been widely published, namely Law Number 22 Year 2009 about Traffic and Road Transport, but in reality there are still many traffic violations committed by the community. The existence of a traffic violation shows less attention to be complied with Law Number 22 Year 2009 about Traffic and Road Transport. Increasing traffic accidents have a major impact on the social environment for people who have not been tested in driving skills can get a Driver's License or a child not yet 16 (sixteen) years old has been held his own motorcycle and free to drive on the highway. Admitted or not, traffic conditions in Indonesia are not currently as expected. Easily the people get the motor with down Payment (DP) and can be repaid every month, causing the number of children under age / teenagers who want a motorcycle. The number of under-age / teenage motorcycle users 
increases every year. This is due to the proliferation of motor products, plus the growing exhibition attitudes in the community. Increased mobility of people supported by the easy ownership of motor vehicles, as well as the development of traffic facilities and the slower of traffic growth, became the factors that caused the high number of traffic accidents. ${ }^{1}$

Lack of assertiveness of the attitude of parents to children, this is what triggers the explosion of motorcycle population on the highway. So the impact on death in adolescence caused by motor accidents, but also the rise of motorcycle gangs are troubling in the social environment of society. The role of education in schools also has the effect of providing traffic teaching, the danger of motoring if not old enough. In addition, the role of government is also needed to call for bad culture of driving on the highway, and all matters relating to safety and security driving to create a conducive environment in a friendly community in traffic.

In addition, the role of parents in improving the traffic discipline for minors also plays an important role, since families or parents are the first education for their children. The influence of the environment and the interaction of peers reflects the child's attitude. Parental supervision here is very important, which is sometimes not enough to prevent using a motorcycle. There are still many who use motorcycles though still under age.

In this case attitude becomes an important thing in human life. Because with the attitude on the self will give the color and style on the person's behavior. According to Secord and Backman states that: "attitude is a certain regularity in terms of feeling (affection), thinking (cognition) and predisposisi actions (konisi) a person to an aspect of the surrounding environment". ${ }^{2}$

From these backgrounds, the better it is to do research in order to raise the legal awareness of children in motorbike riding on the highways, and future law awareness of children to obey

\footnotetext{
Zayu Wiwin Putri. 2012. Traffic Accident Study with Revealed Preference Method in Padang City. (Case Study Student S1 Faculty of Engineering Andalas University). Padang: University of Andalas. PostGraduate program.

2 Azwar Saefudin, 2012, Human Attitude: Theory and its measurement, Student Literature. Yogyakarta, page. 5
}

traffic on the highway in an effort to reduce the number of motor accidents by children. In this study researchers used qualitative descriptive method with data collection methods through In-depth Interview, Observation, and Library Search.

\section{B. DISCUSSION}

1. The Factors that background of Underaged Children Riding Motorcycles on the Highway

Everyone in seeing the personality and behavior of others is very different. So is the interpretation of others in judging what they have seen. Underage motorists do these acts because there are opportunities, hobbies, desires and even just imitate or as a trend today. Whereas in the regulation has not fulfilled sufficient requirements to drive. The factors that underlie motorists are underage, is:

a. Factor of self

Motorists by children or not enough age is increasingly found in several highways and on the Road narrow alleys. The development of an increasingly advanced era requires the society to be forward and facilitate every job quickly. Today's teenagers never pay attention to the risks or dangers of riding a motorcycle without the driver's permission. Different circumstances inside the house outside of maupu is a great influence for the development of children. The role of the family in the formation of the child's personality is needed so that children do not misstep in doing every act.

Some interviews of underage motorists are their own desire because it has become a habit or a hobby. His own desire to ride a motorcycle that can endanger themselves and others.

b. Difficult access from home to school

The difficulty of access from home to school is one of the reasons that the students expressed why they 
use the vehicle without a driver's license.

c. Using Your Own Vehicles for Time and Cost Efficiency

Seeing these conditions in the end most parents are forced to buy their children motorcycles because it is considered more efficient in terms of time and cost even if they realize that their child does not have a driver's license.

d. Factor of Parenthood

The busyness of parents is also one of the reasons why students or minors ride their own motorcycles, many parents do not have enough time to drive and pick up their children because they are busy working. In order for parents to be relieved of the obligation to drive and pick up their sons, they buy their sons motorbikes even though their age is not sufficient for the ownership of the Driving License. A dilemmatic condition, and quite risky, this for most parents is quite difficult, but for the sake of children still continue to go to school, was forced to do so.

e. Factor influence of friend environment

So many phenomenon of juvenile delinquency that can disturb society and add problem in behavior of young generation. The role of the family is one of the important things especially children who still need guidance and direction from a more mature person. Children today are very critical of the circumstances or changes that occur in the environment. Great curiosity of the child makes a challenge for parents today. Focused surveillance, the presence of underage child riders will not be done by children because to be able to ride the motor it takes a sufficient age, skills and driving license obtained from the police station. The desire to berkendara is not only the desire it self from the environment and the friend is very influential in the behavior of children. Adolescence is a period of imitation because the teenager wants to follow what others do without thinking about the consequences.

According to Hidayat the risk of driving a vehicle at high speed increases the risk of being involved in a traffic accident. The high speed makes the difference in the ability to stop. At a speed of 50 $\mathrm{km} / \mathrm{h}$ will be required $41 \mathrm{~m}$ to stop the car, but at a speed of $60 \mathrm{~km} / \mathrm{h}$ it takes a distance of $58 \mathrm{~m}$ to stop the car. This makes a quite significant difference in the chances of a rider involved in an accident. High speed caused the accident to be fatal. Saving time while taking long trips into driver considerations, this is balanced with the use of more fuel. More fuel will be required if the driver drives his vehicle at speeds above $90 \mathrm{~km} / \mathrm{h}$ in a car and more than $80 \mathrm{~km} / \mathrm{h}$ on a truck. The human body is not designed to reduce the impact of an accident, so the greater the impact, the greater the wound it produces. ${ }^{3}$

One method to increase awareness and culture of road safety is to educate and promote the importance of road safety. Education done to children from an early age on the importance of road safety is a way to shape the mindset and character of children. The material of orderly campaigns of traffic is divided according to the age group to facilitate children's understanding of the surrounding environment, especially on road traffic. Road safety materials for elementary school children are grouped into 2 (two) age groups, ie for age group 6 to 8 years and age group 9 to 11 years. Safety education topics developed according to the major theme groups are divided into five, namely traffic recognition, safety in walking, safety in travel, safety in cycling and safety in play. The topic of traffic recognition covers the road and its parts according

3 lbid., 
to Law Number 38 Year 2004 regarding roads, types of vehicles according to Law Number 22 Year 2009 on Traffic and Road Transportation, traffic signs (Regulation of the Minister of Transportation of the Republic of Indonesia PM No. 13 of 2014) and road markings (Regulation of the Minister of Transportation of the Republic of Indonesia No. 34 of 2014) as well as traffic regulations such as Minister of Transportation Regulation No. 111 of 2015 on the procedure for setting speed limits) only for the 9-11 year age group).

Factors that cause traffic accidents There are three factors that cause accidents, namely human factors, vehicles, and the environment. Factors that cause the highest accidents are human factors (human error), caused by careless carelessness, lack of understanding of motorcyclists on driving techniques, traffic ethics, and communication on the road. ${ }^{4}$ The description of each of the factors causing traffic accidents can be explained as follows:

a. Human factor

Human factors can be grouped into two :

\section{a.1. Condition of the Driver}

There are five factors that cause accidents are: the driver's physical, the level of discipline and the understanding of traffic is still low, driver's ability, less visibility (in taking safe distance between vehicles) and violation of the maximum vehicle speed limit.

a.2. Driver Age

Based on the age of traffic accident perpetrators, most aged between 22 to 30 years later followed by the age of 31 to 40 years, where the age range is

\footnotetext{
4 Sugiyanto, G. \& Malkhamah S. 2008. Study of Congestion Costs, Pollution Costs and Road Traffic Accident Expense. International Symposium XI Inter-College Transportation Study Forum (FSTPT). Semarang : Diponegoro University.
}

classified as the age of the most stable emotional level, the level of dexterity and reflex better than other age groups, but usually at this age group mobility level on the road is also very high. If the perpetrators of this accident also at the same time become victims, then this is also the most productive age group. The World Health Organization (WHO) records nearly 1.2 million people worldwide every year killed by road accidents. Of that number, 40 percent are under 25 . Millions more are injured and others have lifelong disabilities (Directorate General of Land Transportation or Directorate General of Hubdat in 2016).

b. Vehicle Factor

Based on data from the Directorate General of Land TransportationDirectorate of Traffic and Road Transport 2016, the types of vehicles involved in traffic accidents are mostly motorcycles with percentage in the last four years averaging $62.62 \%$ followed by passenger car $36 \%$, goods vehicles $29.62 \%$ and buses by $10.56 \%$.

c. Environmental Factor

The third factor causing traffic accidents is the environment. For example, there is a very heavy rain, strong winds, slippery road conditions due to drizzle rain, and others.

The causes of traffic accidents, especially those occurring in children are as follows: ${ }^{5}$

a. The instinct of the child is impulsive and inconclusive.

b. Children are still poor experience.

c. Children are physically smaller than adults.

5 Widjajanti, E. 2012. Development of Cross-Surgical Educational Material for Children, Proceedings of the International Symposium on the Inter-Transportation Transportation Forum (FSTPT) 15. Bekasi: Sekolah Tinggi Transportasi Darat (STTD) West Java. 
d. Children are often not supervised or under-supervised by their parents.

Some studies suggest that children's behavior is lacking in perception, concentration, attention, memory and physical and emotional control; lack of knowledge and understanding of traffic procedures and lack of behavioral patterns in the traffic environment.

2. The Role of Parents and Teachers in Shaping Children's Behavior in Motorcycle Riding on the Highway

Driving for some teenagers is not just an event to show ability or skill, but for them to drive or have a vehicle is a venue to seek or demonstrate their existence. Related to the role of parents and teachers in shaping the behavior of students this research seeks to provide an overview of the process of forming child behavior from home through the role of parents and in school through the role of teachers.

Behavior of teenagers or students sebanarnya more dominated by matters relating to the circle of teenagers themselves. A student may be in the eyes of his parents or in the eyes of his teacher is a submissive child, obedient and orderly, but the behavior when on the road could have turned into disobedient, disorganized and even reckless. Indeed, these conditions can not just be generalized, there are children whose behavior is relatively unchanged.

In essence the influence of peers can have an impact on changes in the behavior of adolescents or students, based on the phenomenon is very reasonable if parents and teachers must synergize each other to not be bored-bosannya remind them to always behave positively, especially on the road, so as not to endanger other road users.

\section{CONCLUSION}

Based on what has been presented in the previous chapter and after analyzing the field findings data. Awareness in driving motorcycles on the highway starts with the completeness of the vehicle letters and safety berkedara. In accordance with the applicable age restrictions related to the ownership of the Driver License, overall to the respondents who have motor vehicle is not yet eligible, because they are not yet 17 years old. Based on this it can be ascertained that when they were asked about the completeness of the letter or the document of the motor vehicle especially the Driving License. The tightness of ownership of Driver License is done to reduce the number of motor accidents and to increase awareness and discipline of traffic.

This study shows the lack of understanding of the students about traffic signs, it happens because of several things, such as the minister of socialization from the police, the discussion about traffic signs is considered not as important things. For most students who are important to those skilled or able to ride a motorcycle, the lack of traffic signs is not something they need to worry about.

To change people's perceptions and paradigms about road safety should be done through continuous education of safety and socialization to communities that begin early to foster a sense of discipline in traffic so that the values of road safety are adopted into values of life.

In This research still have much limitation, so for increase research in the future can be research about safety riding forchildren in the future for obedient traffic. 


\section{BIBLIOGRAPHY}

Azwar Saefudin. 2012. Human Attitude: Theory and its measurement, Pustaka Pelajar. Yogyakarta.

Directorate of Land Transport Safety (DKTD). 2011. Socialization Material of Cross-Sustainability for Children 9 to 11 Years. Jakarta: Directorate General of Land Transportation, Ministry of Transportation.

GITO SUGIYANTO MINA YUMEI SANTI. SCIENTIFIC JOURNAL OF SCIENCE T EKNIKA Vol. 18 No.1, 65-75, May 2015 Characteristics of Traffic Accidents and Early-Age Traffic Safety Education: Case Study in Purbalingga District

Global Road Safety Partnership (GRSP). 2013. Road Safety Education in Schools: Global Road Safety Partnership (GRSP). (online) www.GRSProadsafety.org

Hidayat, T. 2005. Handbook of Procedures for Traffic in Indonesia (Highway Code). Jakarta: Directorate General of Land Transportation, Ministry of Transportation.

Jerry Setiawan Background Adolescent Behavior In Driving Motorcycles Without Driver License. eJournal of Sociatrics Science, 2014, ISSN 0000-0000, ejournal.sos.fisip-unmul.org (C) Copyright 2014

Sugiyanto, G. \& Malkhamah S. 2008. Review of Congestion Costs, Pollution Costs and Road Traffic Accident Costs. International Symposium XI Inter-College Transportation Study Forum (FSTPT). Semarang: Diponegoro University.

Widjajanti, E. (2012) .Development of Cross-Section Education Material for Children, Proceedings of International Symposium on Inter-Transportation Transportation Forum (FSTPT) 15. Bekasi: Sekolah Tinggi Transportasi Darat (STTD) West Java.

Zayu Wiwin Putri. 2012. Traffic Accident Study with Revealed Preference Method in Padang City. (Case Study Student SI Faculty of Engineering Andalas University). Padang: University of Andalas. Graduate program.

Law Number 22 Year 2009 on Road Rule Traffic.

Regulation of the Minister of Transportation of the Republic of Indonesia No. 13 of 2014 and road markings (Regulation of the Minister of Transportation of the Republic of Indonesia No. 34 of 2014)

Regulation of the Minister of Transportation No. 111 of 2015 on the procedures for setting speed limits 